\title{
Blow follows blow for stem-cell work
}

There is no evidence that cloning researcher Woo Suk Hwang created any lines of patientspecific stem cells. The verdict, reached by investigators at Seoul National University (SNU) after daims that Hwang faked his work, confirms stem-cell researchers' worst fears.

In a celebrated paper published last May, the South Korean researcher reported doning cell lines from 11 different patients, which could in principle have been used for therapy (W. S. Hwang et al. Science 308, 1777-1783; 2005). But after several allegations of fraud, a university committee asked three different laboratories to compare the DNA of Hwang's purportedly cloned cell lines with that of the patients who had provided the cells.

On 23 December, the committee reported that the data from the Science paper came from just two cell lines, not eleven as claimed. And on 29 December, it demolished hopes that those two lines would be patient-specific they turned out to match stem-cell lines from embryos produced by in vitro fertilization at MizMedi Hospital in Seoul. MizMedi provided egg cells for Hwang's research.

${ }^{\alpha}$ The committee concludes that there are neither patient-specific stem-cell lines in Hwang's laboratory nor any scientific evidences to support the claim that such cell lines ever existed, said Jung Hye Roe, director of research at the SNU.

According to the Korean press, Hwang has accused a co-author at MizMedi of switching the cell lines. But he submitted his resignation

\section{IMAGE \\ UNAVAILABLE FOR COPYRIGHT REASONS}

In deep: a university panel found no evidence that Woo Suk Hwang created patient-specific lines.

to the SNU on 23 December, and he and several co-authors have asked for the Science paper to be retracted.

On 10 January, the SNU plans to report on two other papers by Hwang's team - a Science paper in which the team daimed to be the first to produce stem cells from a cloned human embryo (W. S. Hwang et al. Science 303, $1669-1674 ; 2004)$, and a Nature paper that reported the first cloned dog (B. C. Lee et al. Nature 436,$641 ; 2005)$. Both journals are running investigations.
And a South Korean bioethics committee will meet on 15 January to look into the charges and other issues concerning egg donation in Hwang's lab. For example, Hwang claimed that he used only 242 eggs for the 2004 paper and 185 for the paper on patient-specific cells. But reports have emerged that say Hwang used more than 1,600 eggs in the experiments. Sung Il Roh, a MizMedi fertility expert and second author on the 2005 Science paper, told Nature that he alone provided 313 mature eggs, from 21 donors, for the 2004 paper and 900 eggs, from 62 donors, for the 2005 paper.

As Nature went to press, PD Notebook, a Korean investigative news programme, was about to air a piece that levels further charges against Hwang. According to one of its producers, the programme will claim that Hwang coerced a junior team member into donating eggs for research. Nature previously reported that this researcher felt obliged to donate eggs after accidentally destroying some early in the experiment. Hwang has not so far responded to Nature's requests for an interview.

Hwang might even find himself facing legal action. According to The Korea Times, government prosecutors could decide to pursue fraud charges after the SNU investigation is complete. Hwang's group received more than 3 billion won (US $\$ 3$ million) for research from the ministry of science and technology last year, and 24 billion won for new facilities.

David Cyranoski

\section{Los Alamos bosses ditched after decade of scandals}

\section{WASHINGTON DC}

Los Alamos National Laboratory will be under fresh management from June. Butstaff wonder whether their new bosses will help the lab move on from the scandals thathave dogged it in the pastdecade.

On21 December, the US Department of Energy announced that the University of California would continue to run the New Mexico institution as part of a consortium thatalso includes three private companies. In a competition for the lab, it beat a partnership between the University of Texas and defence contractor Lockheed
Martin. Los Alamoshas been run by the University of California since it was set up to develop the atomic bomb during the Second World War.

The competition was the firstin the lab'shistory, and was triggered by a series of security scandals, including charges of espionage, an industrial accident and reportedly missing computer dis ks that caused a three-month shutdown in 2004 (see Nature 433, 437;2005).

In announcing the management change, energy department officials were quick to reassure employees who are tired of the recurrent problems. "I cannot stress enough that this is a new contract, witha new team, marking a new approach at Los Alamos," said Samuel Bodman, the US energy secretary. Along with the University of California, the consortium - called Los Alamos NationalSecurity LLC - consists of Bechtel, BWX Technologies and Washington Group International, which are all nuclear-facilities contractors. Some employees think that it will therefore concentrate on nuclear weapons at the expense of basic science. "There is a lot of concern that Los Alamos would become nothing more than a plutonium factory," says Doug Roberts, who recently retired from Los Alamos and runs a widely read blog about the lab.

Michael Anastasio, the lab's new director, has tried to allay such concerns. "This is nota de-emphasison science," says Anastasio, currently director of the Lawrence Livermore National Laboratory in California.

Under the new set-up, the university is expected to run science operations, while the other partners take care of administrative matters, including security. Emma Marris 